\title{
Establishment of seven high yielding grasses on the Texas High Plains
}

\author{
K.L. MARIETTA AND C.M. BRITTON
}

\section{Abstract}

The establishment of several high yielding grasses was examined on the Texas High Plains as an alternative to row crop agriculture. The species were Blackwell switchgrass (Panicum virgatum), El Reno sideoats grama (Bouteloua curtipendula), Morpa weeping lovegrass (Eragrostis curvula) and 4 old world bluestem selections including Caucasian (Bothriochloa caucasica), WW517 (B. intermedia var. indica), Ganada (B. ischaemum var. ischaemum), and WWspar (B. ischaemum var. ischaemum). Each species was seeded in mid-May 1981 and 1982 in Garza County on a fine sand and in Lubbock and Terry Counties on sandy loam soils. Number of seedlings 1 month after planting ranged from $129.7 / \mathrm{m}$ at Brownfield in 1981 to $7.5 / \mathrm{m}$ at Post in 1982. At the end of the first growing season, biomass ranged from $930 \mathrm{~kg} / \mathrm{ha}$ at Lubbock in 1981 to $11 \mathrm{~kg} / \mathrm{ha}$ at Post 1982. At the beginning of the second growing season, basal cover had increased, indicating these species were adapted to the winter conditions in the area. The seedings were successful, and adequate stands of all species were established the first year except for the 1982 Post planting. The year and location were the most important factors in establishment success during this study. There were differences among species, but no one species was superior over locations or years for all the characteristics measured. On the fine sand weeping lovegrass was superior.

Key Words: Panicum virgatum, Bouteloua curtipendula, Eragrostis curvula, Bothriochloa cancasica, Bothriochloa intermedia var. indica, Bothriochloa ischaemum var. ischaemum, germination, yield.

The most critical period in the establishment of a grass stand in semiarid regions is the first growing season following seeding. Establishment is often difficult due to insufficient moisture, high temperatures, high evaporation rates, damage to seedlings by windblown soil particles, and slow growth during the seedling stage (Welch et al. 1962). Many reseeding projects have been attempted throughout the Great Plains with varying degrees of success (Nixon 1949, Burnham 1955, Launchbaugh and Anderson 1963). The Great Plains Council (1966) surveyed grass plantings on the southern High Plains in 1961 and 1962 and reported $50 \%$ of the seedings were successful overall. However, on sandier sites only $20 \%$ were successful. Stuth and Dahl (1972) evaluated seedings following brush control on the Edwards Plateau and found an overall success rate of about $30 \%$. With more intensive seedbed preparation, the success rate increased 65 to $100 \%$ depending on the seedbed and seeding method. Our study was initiated to determine differences among sites, years, and 7 improved grass species with respect to emergence and establishment characteristics.

\section{Study Locations}

Three study areas with course-textured soils were selected. The

Authors were graduate research assistant and associate professor, Department of Range and Wildlife Management, Texas Tech University. Contribution No. T-9-474, College of Agricultural Sciences. Texas Tech University, Lubbock 79409.

Authors wish to thank the SCS Plant Materials Center at Los Lunas, New Mexico, USDA Range Experiment Station at Woodward, Oklahoma, and George Warner Seed Company at Hereford, Texas, for providing seed for this study.

Manuscript accepted 23 December 1988. first site was in Lubbock County. The soil is an Acuff loam, a fine loamy, mixed thermic Aridic Paleustolls (Blackstock 1979). The second site was in Terry County, $5 \mathrm{~km}$ north of Brownfield. The soil at this site is a loamy fine sand of the Amarillo series (Sanders 1962). It is a fine loamy, mixed thermic Aridic Paleustalfs. The third site was located on the Double U Ranch in Garza County. This site is off the Caprock and is more undulating and sandier than the other sites. The soil is fine sand of the Brownfield Series and is classified as a loamy, mixed thermic Arenic Aridic Paleustalfs (Richardson et al. 1975).

The climate of the southern High Plains is warm temperate, subtropical and characterized by dry winters, long summers, high winds, and high evaporation. The average freeze free period is 211 days from early April to early November (NOAA 1981). Precipitation averages about $460 \mathrm{~mm}$ annually. Three-fourths of the rainfall occurs during the warm season of April through October. However, monthly and annual totals vary greatly. In the 3 counties included in this study, annual precipitation has ranged from 81 to $1,100 \mathrm{~mm}$.

Total soil nitrogen was measured using standard micro-Kjeldahl techniques (AOAC 1980). Average nitrogen levels varied among locations and ranged from $0.073 \%$ at Lubbock to $0.030 \%$ at Post for the 0-60 cm soil core. Brownfield was intermediate with $0.043 \%$ nitrogen in the soil.

\section{Methods}

Seven species were selected for evaluation and included 2 native and 5 introduced grasses. The native grasses were Blackwell switchgrass (Panicum virgatum L.) and El Reno sideoats grama [Bouteloua curtipendula (Michx.) Torr.]. Introduced grasses were Morpa weeping lovegrass [Eragrostis curvula (Schrad.) Nees.] and 4 old world bluestems (OWB) which included Caucasian [Bothriochloa caucasia (Trin.) C.E. Hubb.], WWspar [B. ischaemum (L.) King var. ischaemum], Ganada [B. Ischaemum (L.) Keng var. ischaemum], and WW 517 [B. intermedia (R.Br.) var. indica].

All species were seeded in 1981 and 1982 . In 1981 a seedbed was prepared at all locations by disking early in the spring. The areas were disked again and cultipacked about 2 weeks before planting to remove the competing vegetation and to prepare a firm seedbed. In 1982 a litter mulch was used as the seedbed preparation technique in 1982. Wheat was drilled into freshly disked seedbeds at Lubbock and Brownfield and broadcast and cultipacked at Post in the late summer of 1981. Before planting in May 1982 the wheat and invading vegetation were sprayed with glyphosate $(1 \%)$ to create a litter mulch.

A seeding rate of $215 \mathrm{PLS} / \mathrm{m}$ of row was used with a $1-\mathrm{m}$ row spacing. The plots were planted 11-14 May 1981 and 1982 with a 1 row Almaco V-belt push planter. A seeding depth of about $1 \mathrm{~cm}$ was used for all species (Robertson and Box 1969, Cross 1983). Each plot consisted of 5 rows, $8 \mathrm{~m}$ in length. There were 6 replications of each species (treatments) at each location arranged in a randomized block design.

Soil moisture was randomly measured gravimetrically (Gardner 1965 ) over the area every 2 weeks during the growing season and 

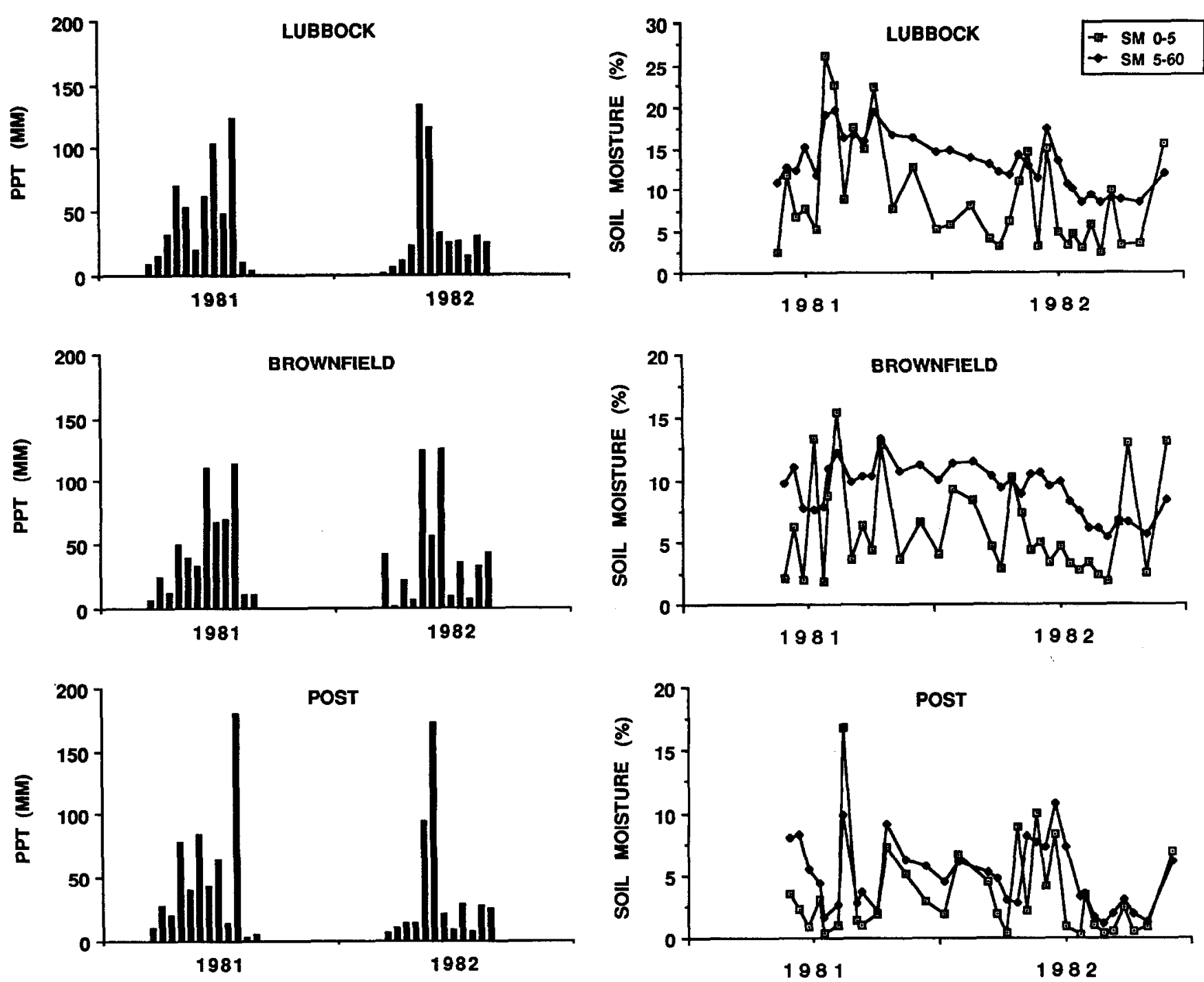

Fig. 1. Monthly precipitation for 3 study sites in west Texas.

monthly during the remainder of the year. Samples were taken at $0-5$ and 5-60 cm depths.

Field data were collected to determine emergence, establishment, first year production, and overwintering ability. Each set of data included 5 randomly located samples from each plot. In mid-June, about 1 month after planting, the number of seedlings was determined per $0.5 \mathrm{~m}$ of row. In late September or October, measurements were taken to determine establishment and included basal cover in $1 \mathrm{~m}$ of row. Leaf canopy height and number of flowering culms were also measured for each basal cover segment.

In mid-September first-year production was measured by hand clipping all plants from $1 \mathrm{~m}$ of row to a $1-\mathrm{cm}$ stubble height. The samples were dried at $50^{\circ} \mathrm{C}$ for $48 \mathrm{hr}$ then weighed. Overwintering survival was determined by measuring basal cover of green culms during 1 May after planting. Basal cover information from September and the following May were compared using a $t$-test to determine if changes had occurred during winter.

Statistical analysis consisted of analysis of variance and LSD mean separation test $(P=0.05)$ among species for each location and year. Analysis of variance across locations and years was performed with location as main plot, year as sub-plot, and species as sub-subplot in a split-split block design.

Fig. 2. Biweekly soll moisture at 2 depths (cm) for 3 study sites in west Texas.

\section{Results}

During this study, annual rainfall varied from $564 \mathrm{~mm}$ at Post in 1981 to $377 \mathrm{~mm}$ at Brownfield in 1982 (Fig. 1). These totals range from $86 \mathrm{~mm}$ above to $60 \mathrm{~mm}$ below the long-term average. Of the 2 years studied, 1981 had the highest total precipitation and more favorable distribution of rainfall during the growing season. This provided more beneficial conditions for plant growth than in 1982 or 1983. Late July and August rains resulted in increased growth late in the growing season. Soil moisture is presented in Figure 2.

Of the 6 plantings, ( 3 locations, 2 years), 5 were successful for all species based on 10 seedlings/m (Vallentine 1971) as the number needed for adequate stand establishment (Fig. 3). The 1982 seeding at Post failed.

The greatest difference in emergence, establishment, and overwintering characteristics was between planting years. Characteristics were also different for all locations. However, Brownfield and Lubbock were often similar and the difference was a result of reduced values at Post. Species responses were different for each measurement taken within years and locations except for dry weight at Brownfield in 1981 and 1982 and flower culm numbers at Lubbock and Post in 1982. 


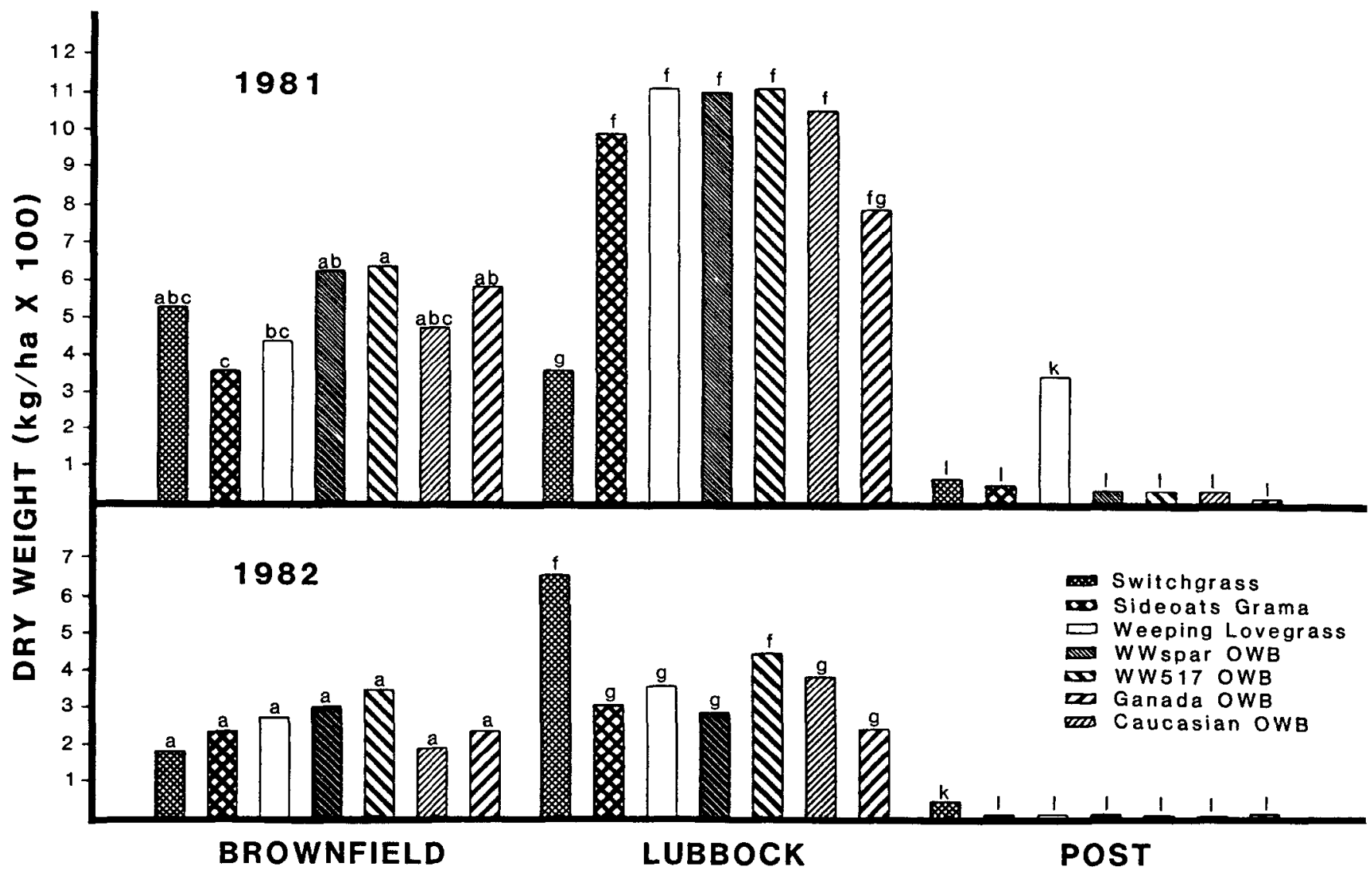

Fig. 4. Establishment dry weight $(\mathrm{kg} / \mathrm{ha})$ for each species grouped by year and location. Within each year and location bars with the same letter were not significantly different at $\mathrm{P}=0.05$ as determined by LSD test.

Table 1. Establishment and overwintering characteristics for each location. These included the number of flowering culms and leaf canopy height.

\begin{tabular}{|c|c|c|c|c|c|c|c|c|}
\hline \multirow[b]{2}{*}{$\begin{array}{l}\text { Location } \\
\text { characteristics }\end{array}$} & \multirow[b]{2}{*}{ Date } & \multicolumn{7}{|c|}{ Species } \\
\hline & & Switchgrass & $\begin{array}{c}\text { Sideoats } \\
\text { grama }\end{array}$ & $\begin{array}{l}\text { Weeping } \\
\text { lovegrass }\end{array}$ & $\begin{array}{c}\text { WWspar } \\
\text { OWB }\end{array}$ & $\begin{array}{c}\text { WW517 } \\
\text { OWB }\end{array}$ & $\begin{array}{c}\text { Ganada } \\
\text { OWB }\end{array}$ & $\begin{array}{c}\text { Caucasain } \\
\text { OWB }\end{array}$ \\
\hline \multicolumn{9}{|l|}{ Brownfield } \\
\hline $\begin{array}{l}\text { Flower culm } \\
\text { (no./m) } \\
\text { Leaf canopy } \\
\text { (cm) }\end{array}$ & $\begin{array}{l}\text { Sep } 81 \\
\text { Sep } 82 \\
\text { Sep } 81 \\
\text { Sep } 82\end{array}$ & $\begin{array}{l}9.2 \mathrm{c}^{*} \\
3.2 \mathrm{c} \\
41.3 \mathrm{a} \\
25.3 \mathrm{~b}\end{array}$ & $\begin{array}{l}75.5 b c \\
82.5 b \\
23.5 b \\
19.7 b c\end{array}$ & $\begin{array}{r}4.3 \mathrm{c} \\
6.8 \mathrm{c} \\
42.9 \mathrm{a} \\
33.7 \mathrm{a}\end{array}$ & $\begin{array}{c}226.2 \mathrm{a} \\
174.7 \mathrm{a} \\
22.7 \mathrm{~b} \\
21.5 \mathrm{bc}\end{array}$ & $\begin{array}{l}71.0 \mathrm{ab} \\
92.2 \mathrm{~b} \\
17.5 \mathrm{~b} \\
15.7 \mathrm{c}\end{array}$ & $\begin{array}{c}202.0 \mathrm{a} \\
119.3 \mathrm{~b} \\
31.2 \mathrm{ab} \\
19.2 \mathrm{bc}\end{array}$ & $\begin{array}{r}234.7 \mathrm{a} \\
160.7 \mathrm{a} \\
41.2 \mathrm{a} \\
24.2 \mathrm{~b}\end{array}$ \\
\hline \multicolumn{9}{|l|}{ Lubbock } \\
\hline $\begin{array}{l}\text { Flower culm } \\
\text { (no./m) } \\
\text { Leaf canopy } \\
(\mathrm{cm})\end{array}$ & $\begin{array}{l}\text { Sep } 81 \\
\text { Sep } 82 \\
\text { Sep } 81 \\
\text { Sep } 82\end{array}$ & $\begin{array}{l}27.3 \mathrm{c} \\
35.0 \mathrm{bc} \\
38.0 \mathrm{~b} \\
46.2 \mathrm{a}\end{array}$ & $\begin{array}{c}209.3 \mathrm{bc} \\
65.3 \mathrm{abc} \\
28.8 \mathrm{~cd} \\
24.4 \mathrm{c}\end{array}$ & $\begin{array}{l}22.8 \mathrm{c} \\
23.7 \mathrm{c} \\
50.3 \mathrm{a} \\
33.9 \mathrm{~b}\end{array}$ & $\begin{array}{l}852.5 \mathrm{a} \\
106.5 \mathrm{abc} \\
27.2 \mathrm{~cd} \\
12.4 \mathrm{e}\end{array}$ & $\begin{array}{c}398.7 \mathrm{~b} \\
118.5 \mathrm{ab} \\
24.3 \mathrm{~cd} \\
14.2 \mathrm{de}\end{array}$ & $\begin{array}{r}361.8 \mathrm{~b} \\
146.8 \mathrm{a} \\
23.8 \mathrm{~d} \\
12.6 \mathrm{e}\end{array}$ & $\begin{array}{l}437.8 \mathrm{~b} \\
81.8 \mathrm{abc} \\
31.0 \mathrm{c} \\
16.4 \mathrm{~d}\end{array}$ \\
\hline \multicolumn{9}{|l|}{ Post } \\
\hline $\begin{array}{l}\text { Flower culm } \\
\text { (no./m) } \\
\text { Leaf canopy } \\
\text { (cm) }\end{array}$ & $\begin{array}{l}\text { Sep } 81 \\
\text { Sep } 82 \\
\text { Sep } 81 \\
\text { Sep } 82\end{array}$ & $\begin{array}{c}4.7 \mathrm{bc} \\
0.8 \mathrm{a} \\
26.2 \mathrm{~b} \\
16.2 \mathrm{a}\end{array}$ & $\begin{array}{c}4.7 \mathrm{bc} \\
0.2 \mathrm{a} \\
11.2 \mathrm{c} \\
7.5 \mathrm{bcd}\end{array}$ & $\begin{array}{r}1.2 \mathrm{c} \\
0.5 \mathrm{a} \\
28.7 \mathrm{a} \\
10.2 \mathrm{~b}\end{array}$ & $\begin{array}{c}34.7 \mathrm{a} \\
1.5 \mathrm{a} \\
10.3 \mathrm{~cd} \\
8.9 \mathrm{bc}\end{array}$ & $\begin{array}{c}25.7 \mathrm{ab} \\
0.5 \mathrm{a} \\
11.3 \mathrm{c} \\
8.1 \mathrm{bc}\end{array}$ & $\begin{array}{l}16.3 \mathrm{abc} \\
0.3 \mathrm{a} \\
5.3 \mathrm{~d} \\
5.5 \mathrm{~cd}\end{array}$ & $\begin{array}{l}3.7 \mathrm{bc} \\
0.0 \\
7.3 \mathrm{~cd} \\
3.9 \mathrm{~d}\end{array}$ \\
\hline
\end{tabular}

*Within each row the values followed by the same letter were not significantly different at $P=0.05$ as determined by LSD test.

\section{Discussion}

The year and location were the most important factors in establishment success during this study. The rainfall amounts and patterns and the resulting soil moisture conditions were adequate for establishment in both years. However, the observed difference between years was probably a result of these environmental factors and soil and air temperatures which are considered the main envi- ronmental variables that contribute to successful stand establishment (Fults 1944, Moldenhauer 1959, Hudspeth and Taylor 1961). In addition, we used different seedbed preparation techniques. In 1981 cleaned, tilled seedbeds were used while in 1982 a stubble mulch and herbicide were used. When the danger of soil erosion is great and/or improvement of water and temperature conditions at the soil surface is needed, a stubble mulch is generally recommended (Launchbaugh and Owensby 1978). However, a clean, 


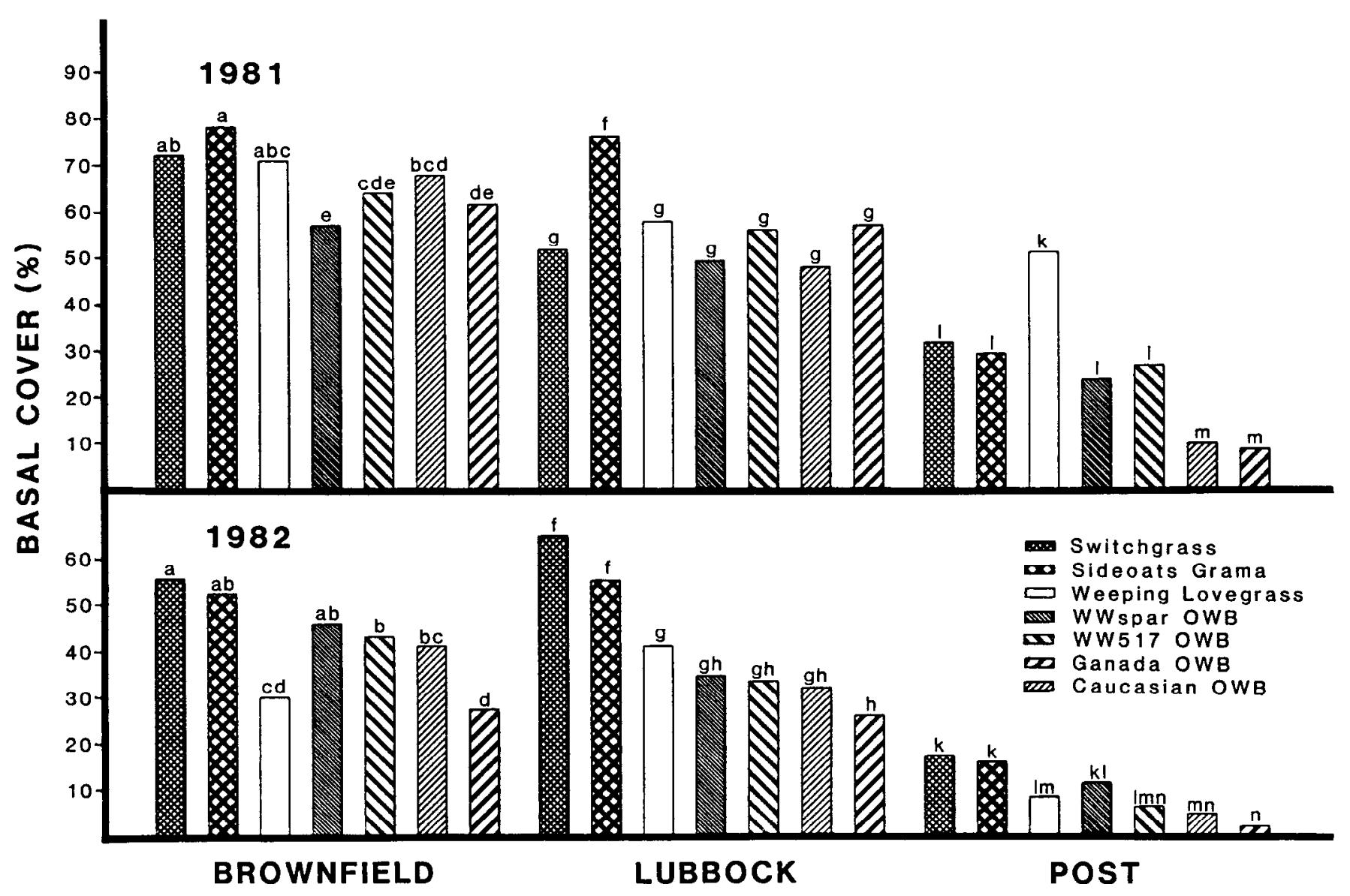

Fig. 5. Overwintering basal cover (\%) for each species grouped by year and location. Within each year and location the bars with the same letter were not significantly different at $\mathrm{P}=0.05$ as determined by LSD test.

tilled seedbed often gives as good or better results (Fults 1944, Dudley and Holt 1963) as in this study.

The failure at Post in 1982 apparently resulted from the method of seedbed preparation and the resulting competition from sandburs (Cenchrus incertus M.A. Curtis) that became established soon after planting. Abundant weeds often reduce grass establishment and first year production (Launchbaugh and Owensby 1978, Martin et al. 1982). Another factor indicating that the failure was due to seedbed preparation was seeding results obtained by Cotter and Dahl (1982) the same year and at the same location for weeping lovegrass. They reported that 38 to 41 plants $/ \mathrm{m}$ were established at the end of the 1982 growing season with double disking and moldboard plowing as seedbed preparation techniques. However on the no-till plots no plants established.

General establishment success during our study was considerably higher than the success rates reported in the literature for the southern High Plains (Great Plains Council 1966). On sandy soils $20 \%$ of the seedlings were successful while on the tighter soils $49 \%$ had at least 10 seedlings/m. Sideoats grama, switchgrass, and weeping lovegrass produced successful stands 54,30 , and $57 \%$ of the time, respectively. In contrast, we achieved much better success for these species.

The seedling numbers were higher in our study than those previously reported for the same species (Pettit et al. 1976, Brock et al. 1984). The seedling counts for that work were generally madc at the end of the first growing season rather than 1 month after planting. However, in our study individual plants could not be distinguished at the end of the first growing season. Since basal cover increased or was constant from June to September, except at Post, most of the seedlings probably survived or individual plants increased enough in size for basal cover to remain constant. At Post in 1981 basal cover was reduced about $50 \%$ overall as a result of seedling death. This reduction was probably the result of competition from weedy species and stress due to low soil moisture levels in July.

Seedling numbers for weeping lovegrass from other studies at the Post site range from 0 to 41 seedlings/ $\mathrm{m}$ in 1982 and from 0 to 5 seedlings/ $\mathrm{m}$ in 1983 (Cotter and Dahl 1982 and 1983). The range of values was probably the result of seedbed preparation techniques. Where weed competition was reduced, higher plant numbers were recorded. In comparison with our study, weeping lovegrass seedling numbers were $108.7 / \mathrm{m}$ in 1981 and $9.5 / \mathrm{m}$ in 1982 . The 1982 values were less than those recorded with the moldboard plowing or double disking treatments the same year. At the Brownfield site in 1976 and 1977 , weeping lovegrass was planted using various seeding equipment (Pettit et al. 1976). Seedling numbers averaged $9.5 / \mathrm{m}$ in 1976 and ranged from 2.7 to $6.9 / \mathrm{m}$ in 1977 . During the present study, weeping lovegrass seedling numbers at Brownfield were $114.3 / \mathrm{m}$ in 1981 and $21.7 / \mathrm{m}$ in 1982 .

Production values for the first growing season are generally not reported in conjunction with seeding trials. Values that have been reported are usually from fertilizer or herbicide trials. Depending on weed control methods and site, dry weight has ranged from no harvestable yield to $9,180 \mathrm{~kg} /$ ha for switchgrass and from 220 to $4,440 \mathrm{~kg} /$ ha for sideoats grama in Nebraska (Martin et al. 1982). Dalrymple (1970) stated that first year yields of weeping lovegrass in Oklahoma often reach 4,000 to $6,000 \mathrm{~kg} / \mathrm{ha}$, and that values presented from a fertilizer study ranged from $728 \mathrm{~kg} /$ ha to 2,105 $\mathrm{kg} / \mathrm{ha}$. These first year yields are higher than in our study. 
In summary, there were differences among species. However, they were not as important as the year and location effects. On the deep sandy land site at Post, weeping lovegrass was superior to the other species but on the sandy loam soils all of the species performed well.

\section{Literature Cited}

AOAC. 1980. Official methods of analysis. 13th edition. Assoc. Off. Anal. Chem. Washington, D.C.

Blackstock, D.A. 1979. Soil survey of Lubbock County, Texas. USDA Soil Conserv. Serv.

Brock, J.H., H.T. Wiedeman, and C.E. Fisher. 1984. Seeding results of selected range forage material. Texas Agr. Exp. Sta. MP-1542.

Burnham, D.R. 1955. Reseeding abandoned cropland or depleted range areas. New Mexico Agr. Exp. Sta. Bull. 395.

Cotter, P.F., and B.E. Dahl. 1982. Seedbed preparation for sandbur control on sandy soils. Research Highlights Noxious Brush and Weed Control, Texas Tech Univ. 13:43.

Cotter, P.F., and B.E. Dahl. 1983. Seedbed preparation for sandbur control on sandy soils. Research Highlights Noxious Brush and Weed Control. Texas Tech Univ. 14:26.

Cross, B. 1983. Seedbeds and seeding methods. p. 20-25. In: H.T. Wiedeman and J.F. Cadenhead. Proc. Range and Pasture Seeding in the Southern Great Plains Symp. Vernon, Texas.

Dalrymple, R.L. 1970. Weeping lovegrass establishment and management of first year stands. p. 21-28. In: R.L. Dalrymple. Proc. First Weeping Lovegrass Symp. Nobel Foundation. Ardmore, Okla

Dudley, D.I., and E.C. Holt. 1963. Establishment of warm season grasses on the Grand Prairie. Texas Agr. Exp. Sta. Misc. Pub. MP672.

Fults, J.L. 1944. Some factors affecting the establishment of perennial grass for erosion control in eastern Colorado. Agron. J. 36:615-625.

Gardner, W.H. 1965. Water content. p. 92-96. In: C.A. Black. Methods of soil analysis. Amer. Soc. Agron. Mono. 9.

Great Plains Council. 1966. A stand establishment survey of grass plantings in the Great Plains. Nebraska Agr. Exp. Sta. Rep. 23.
Hudspeth, E.B., and H.M. Taylor. 1961. Factors affecting seedling emergence of Blackwell switchgrass. Agron. J. 53:331-335.

Launchbaugh, J.L., and K.L. Anderson. 1963. Grass reseeding investigations at Hays and Manhattan, Kansas, Kansas Agr. Exp. Sta. Bull. 622.

Launchbaugh, J.L., and C.E. Owensby. 1970. Seeding rate and first-year stand relationships for six native grasses. J. Range Manage. 23:414-417.

Leunchbaugh, J.L., and C.E. Owensby. 1978. Kansas rangelands, their management based on a half century of research. Kansas Agr. Exp. Sta. Bull. 128.

Marietta, K.L. 1985. Forage alternatives for dryland agriculture on the Texas High Plains. Ph.D. Diss., Texas Tech Univ., Lubbock.

Martin, A.R., R.S. Moomaw, K.P. Vogel. 1982. Warm-season grass establishment with atrazine. Agron. J. 74:916-920.

Moldenhauer, W.C. 1959. Establishment of grasses on sandy soil of the southern High Plains of Texas using a mulch and simulated moisture levels. Agron. J. 51:39-46.

Nixon, W.M. 1949. Range reseeding in Texas and Oklahoma. J. Range Manage. 2:213-217.

NOAA. 1981 to 1983. Monthly climatological data summaries, Texas. 86-88. Nat.Oceangr. Atmos. Admin. Asheville, N.C.

Pettit, R.D., D.N. Ueckert, and B.E. Dahl. 1976. Seeding on sandy sites in West Texas. Research Highlights Noxious Brush and Weed Control. Texas Tech Univ. 7:15.

Richardson, W.E., D.G. Grica, and L.A. Putman. 1975. Soil survey of Garza County, Texas. USDA Soil Conserv. Serv.

Robertson, T.E., and T.W. Box. 1969. Interseeding sideoats grama on the Texas High Plains. J. Range Manage. 22:242-243.

Sanders, D. 1962. Soil survey of Terry County, Texas. USDA Soil Conserv. Serv.

Stubbendieck, J., P.T. Koshi, and W.G. McCully. 1973. Establishment and growth of selected grasses. J. Range Manage. 26:39-41.

Stuth, J.W., and B.E. Dahl. 1972. Evaluation of rangeland seeding following mechanical brush control in Texas. J. Range Manage. 27:146-149.

Vallentine, J.F. 1971. Range development and improvements. Brigham Young Univ. Press. Provo, Utah.

Welch, N.H., E. Burnett, and E.B. Hudspeth. 1962. Effect of fertilizer on seedling emergence and growth of several grass species. J. Range Manage. 15:92-98.

\section{If you read or write. .}

in the field of range management, you need the Third (1989) Edition of $\mathbf{A}$ Glossary of Terms Used In Range Management. Compiled and edited by the Glossary Revision Special Committee of the Society for Range Management, this new edition presents current definitions of range management terms as well as references to earlier terminology. The Glossary is designed to help students and others entering the field of range management as well as those currently using the literature. Copies are $\$ 5.00$ (US) from the Soclety for Range Management, 1839 York Street, Denver, CO 80206. Telephone: (303)355-7070. 